\title{
Life cycle assessment of sewage sludge management options including long-term impacts after land application
}

Yoshida, Hiroko; ten Hoeve, Marieke; Christensen, Thomas Højlund; Bruun, Sander; Jensen, Lars S.; Scheutz, Charlotte

Published in:

Journal of Cleaner Production

Link to article, DOI:

10.1016/j.jclepro.2017.10.175

Publication date:

2018

Document Version

Peer reviewed version

Link back to DTU Orbit

Citation (APA):

Yoshida, H., ten Hoeve, M., Christensen, T. H., Bruun, S., Jensen, L. S., \& Scheutz, C. (2018). Life cycle assessment of sewage sludge management options including long-term impacts after land application. Journal of Cleaner Production, 174, 538-547. https://doi.org/10.1016/j.jclepro.2017.10.175

\section{General rights}

Copyright and moral rights for the publications made accessible in the public portal are retained by the authors and/or other copyright owners and it is a condition of accessing publications that users recognise and abide by the legal requirements associated with these rights.

- Users may download and print one copy of any publication from the public portal for the purpose of private study or research.

- You may not further distribute the material or use it for any profit-making activity or commercial gain

- You may freely distribute the URL identifying the publication in the public portal 


\section{Accepted Manuscript}

Life cycle assessment of sewage sludge management options including long-term impacts after land application

Hiroko Yoshida, Marieke ten Hoeve, Thomas H. Christensen, Sander Bruun, Lars S. Jensen, Charlotte Scheutz

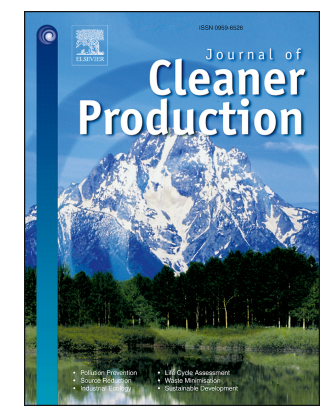

PII: S0959-6526(17)32482-4

DOI: 10.1016/j.jclepro.2017.10.175

Reference: JCLP 10967

To appear in: Journal of Cleaner Production

Received Date: 26 April 2017

Revised Date: 4 October 2017

Accepted Date: 16 October 2017

Please cite this article as: Yoshida $\mathrm{H}$, ten Hoeve M, Christensen TH, Bruun S, Jensen LS, Scheutz C, Life cycle assessment of sewage sludge management options including long-term impacts after land application, Journal of Cleaner Production (2017), doi: 10.1016/j.jclepro.2017.10.175.

This is a PDF file of an unedited manuscript that has been accepted for publication. As a service to our customers we are providing this early version of the manuscript. The manuscript will undergo copyediting, typesetting, and review of the resulting proof before it is published in its final form. Please note that during the production process errors may be discovered which could affect the content, and all legal disclaimers that apply to the journal pertain. 
1 Life cycle assessment of sewage sludge management options including long-term 2 impacts after land application

3

4 Hiroko Yoshida ${ }^{1}$, Marieke ten Hoeve ${ }^{1,2}$, Thomas H. Christensen ${ }^{1}$, Sander Bruun ${ }^{2}$, Lars S. Jensen ${ }^{2}$, 5 Charlotte Scheutz ${ }^{1 \S}$

$6 \quad{ }^{I}$ Department of Environmental Engineering, Technical University of Denmark, Kgs. Lyngby, Denmark

$7 \quad{ }^{2}$ Department of Plant and Environmental Sciences, University of Copenhagen, Thorvaldsensvej 40, $8 \quad$ Frederiksberg 1871, Denmark

9

$10{ }^{\S}$ Corresponding author

11 Email: chas@env.dtu.dk

12

13 Keywords:

14 Sludge treatment, anaerobic digestion, incineration, lime stabilisation, land application, organic 15 fertiliser, emission factors 


\section{Abstract}

A life cycle assessment (LCA) was performed on five commonly applied sewage sludge treatment practices: dewatering of mixed sludge (DMS), lime stabilisation of dewatered sludge (LIMS), anaerobic digestion of mixed sludge (ADS), dewatering of anaerobically-digested sludge (DADS) and incineration of dewatered anaerobically-digested sludge (INC). In the first four scenarios, the sludge residues were applied on agricultural land, while in the fifth scenario ash from sludge incineration was landfilled. It was found that the sludge treatment technology influenced in which processes $\mathrm{C}$ and $\mathrm{N}$ emissions happened. In general, the INC scenario performed better than or comparably to the scenarios with land application of the sludge. Human toxicity (non-carcinogenic) and eco-toxicity showed the highest normalised impact potentials for all the scenarios with land application. In both categories, impacts were dominated by the application of zinc and copper to agricultural soil. For the eutrophication potentials, different scenarios appeared beneficial depending on the receiving compartment in focus. The fate of $\mathrm{P}$ dominated freshwater eutrophication, while the fate of $\mathrm{N}$ had a profound effect on all non-toxic impact categories other than freshwater eutrophication. The sensitivity analysis showed that the results were sensitive to soil and precipitation conditions. The ranking of scenarios was affected by local conditions for marine eutrophication. Overall, the present study highlighted the importance of including all sludge treatment stages and conducting a detailed $\mathrm{N}$ flow analysis, since the emission of reactive $\mathrm{N}$ into the environment is the major driver for almost all nontoxic impact categories.

\section{Introduction}

Plant nutrients such as nitrogen $(\mathrm{N})$ and phosphorus $(\mathrm{P})$, which are discharged with wastewater from urban areas, end up concentrated in sewage sludge when the wastewater is treated in a wastewater treatment plant (e.g. Qiao et al., 2011; Morée et al., 2013). Properly treated sewage sludge is therefore commonly applied to land as a fertiliser and soil conditioner, although the risk of soil contamination and pathogen transmission cannot be ignored (Singh and Agrawal, 2008). Part of the organic carbon (C) in sewage sludge is resistant to biodegradation in the soil, leading to $\mathrm{C}$ build-up in the soil that in turn contributes to climate change mitigation and soil quality improvement (Lal, 2004;

Singh and Agrawal, 2008). 
Life cycle assessment (LCA) is applied in order to quantify the environmental burdens and benefits of treating and utilising sewage sludge. Most studies included in a recent review by Yoshida et al. (2013) only address the environmental impacts associated with land application of sludge in rather simple terms, by including 1) the fuel requirement for bringing sludge to agricultural land and incorporating it into the soil, 2) the introduction of heavy metals onto agricultural land and 3) the avoided production of conventional mineral fertiliser due to its substitution by sewage sludge. Moreover, of the 28 reviewed studies that included land application, 14 studies included gaseous emissions associated with the land application of sludge (e.g. methane $\left(\mathrm{CH}_{4}\right)$, nitrous oxide $\left(\mathrm{N}_{2} \mathrm{O}\right)$ and ammonia $\left(\mathrm{NH}_{3}\right)$ ), three studies included soil $\mathrm{C}$ storage, while four studies considered nutrient leaching and runoff. The most comprehensive sludge management studies have revealed that land application is a major contributor to global warming, eutrophication and acidification (Johansson et al., 2008; Peters and Rowley 2009; Brown et al., 2010; Hospido et al., 2010). The gaseous emissions data in most studies were either default national greenhouse gas emission factors proposed by the Intergovernmental Panel on Climate Change (IPCC, 2006) or default life cycle inventory data taken from the Ecoinvent database. This database is based on studies conducted in Switzerland and has not been specifically developed for the use of sewage sludge on land (Schmid et al., 2000, 2001).

With respect to $\mathrm{N}$ leaching, sewage sludge behaves differently from the mineral fertiliser it substitutes since a sizeable part of the $\mathrm{N}$ in sewage sludge is organically bound and becomes available to plants continuously as it mineralises. However, mineralisation continues even when plants do not actively take up $\mathrm{N}$ for growth, leading to a higher loss of $\mathrm{N}$ to ground and surface water (Basso and Ritchie, 2005; Yoshida et al., 2015b). The rate of $\mathrm{C}$ and $\mathrm{N}$ mineralisation in sewage sludge after soil application is affected by the treatment of the sludge before land application. The more the sludge is stabilised prior to application, the likelier it is that $\mathrm{C}$ and $\mathrm{N}$ will remain in the soil for a prolonged period (Cabrera et al., 2005; Yoshida et al., 2015b).

One way of addressing the emissions associated with land application of sewage sludge in a more consistent way is through the use of advanced agro-ecosystem models. These models simulate the turnover and movement of elements within the soil-plant systems and can be used to estimate relevant emission factors such as plant uptake, emission of greenhouse gases, nitrate leaching and C sequestration. Bruun et al. (2016) used the DAISY agro-ecosystem model to simulate long-term consequences of land application of a range of different sewage sludge types. The simulations were 
based on the observed mineralisation patterns obtained in laboratory incubations of the different sludge types (Yoshida et al., 2015b) and were used to calculate emission factors directly applicable in life cycle assessments.

The purpose of this study was to evaluate the environmental aspects of five sewage sludge management options. The assessment began with mixed sludge generated by a wastewater treatment plant (WWTP) it covered treatment and ended with the final application of the treated sludge on land or landfilling of ash from sludge incineration. The assessment was based on simulations conducted by Bruun et al. (2016). For C and N, long-term dynamics and emissions after land application were included in the assessment of sludge management, something that, to our knowledge, has not been done in LCA before. Furthermore, variations in emission factors according to soil type, crop production and regional weather conditions were neglected in nearly all previous studies.

\section{Methodology}

This study follows the methods delineated in the ISO 14040 standard for LCAs. The goal and scope definitions, life cycle inventory (LCI), life cycle impact assessment method (LCIA) and interpretation of the results are presented below. Supplementary Information (SI) is available online to provide details on assumptions, parameter values and data sources.

\subsection{Goal and scope definition}

The goal of this study was to assess the environmental profile of five sewage sludge treatment options when including technology-specific, long-term emissions after land application. The study was conducted for the purposes of research and the evaluation of the results was limited to a discussion of the fate of $\mathrm{C}, \mathrm{N}$ and $\mathrm{P}$ and the major sludge treatment stages contributing to a selection of impact categories, with a reflection on the influence of local conditions on the impact potentials.

The functional unit considered in this study was the treatment and disposal of $1000 \mathrm{~kg}$ of mixed sludge, consisting of $46.32 \%$ primary sludge, $53.02 \%$ thickened secondary sludge and $0.67 \%$ fat, oil and grease. The mixed sludge that formed the starting point for this analysis is one of the outputs of the wastewater treatment process. The composition of the sludge was based on a sample taken at the Avedøre municipal wastewater treatment plant (WWTP) serving 256,000 inhabitants in the Greater Copenhagen area, Denmark (Yoshida et al., 2015a). $1000 \mathrm{~kg}$ of mixed sludge corresponds to the sludge 
generated by 1.17 inhabitants in one year. A detailed description of the WWTP and the composition of the generated mixed sewage sludge is available in the SI of this paper (section SI-1). The total solid (TS) content of the mixed sludge was $3.4 \%$ and the volatile solid (VS) content was $75.2 \%$ of TS. In this study, the $\mathrm{C}$ in sewage sludge was considered biogenic in origin.

An attributional LCA modelling approach was chosen since the primary goal was to evaluate the influence of long-term emissions after land application of sludge and associated uncertainties, and not to assess the potential impacts of introducing any changes into an existing system. The multifunctionality problem was addressed by using system expansion, including electricity and chemical production for upstream processes and the production and use of substitutes (electricity, process heat and mineral fertiliser) for downstream processes.

Five sludge treatment scenarios were considered:

- DMS - dewatering of mixed sludge followed by land application

- LIMS - lime addition to mechanically dewatered sludge followed by land application

- ADS - anaerobic digestion of mixed sludge followed directly by land application

- DADS - dewatering of anaerobically-digested sludge followed by land application

- INC - incineration of dewatered anaerobically-digested sludge and landfilling of ash.

These five sludge treatment scenarios were chosen because they are typical management options for centralised European municipal wastewater treatment systems (Fytili and Zabaniotou, 2008). It should be noted that DMS and LIMS are theoretical scenarios since all the sludge generated by the WWTP analysed in this study was anaerobically digested.

The system boundaries of this study included all the processes taking place after the generation of mixed sludge up to its final land application or disposal in a landfill, including all emissions to air, water and soil (Fig. 1). The time horizon of the assessment was set at 100 years for both the emission inventory and the impact assessment. The geographical boundary of this study was Denmark and the reference year was 2011, the year in which most of the operational data were collected. Site and timespecific information was used where possible.

\subsection{Life cycle inventory}

LCA modelling was conducted using EASETECH (Environmental Assessment System for Environmental TECHnologies), a mass flow-based LCA tool, which allows for a detailed modelling of 
substance flows through the system and of the relationships between flows and emissions (Clavreul $e t$ al., 2014). In this study, EASETECH ver. 05.02.14 was used, while emissions embedded in the production of electricity, treatment chemicals (lime, $\mathrm{NaOH}, \mathrm{FeCl}_{3}$, and polymer coagulant) and mineral fertiliser were taken from Ecoinvent 2.2 (SI-2).

Emission and operational data for mechanical dewatering, anaerobic digestion, biogas utilisation and treatment of reject water were based on measurements from the Avedøre WWTP. For dewatering, it was assumed that a decanter centrifuge was used for mixed sludge and for anaerobicallydigested sludge (SI-3). No emissions from the dewatering process were assumed. The lime dosage rate and energy requirement for the mixer were based on data from the Staffanstorps WWTP in southern Sweden, and any loss of $\mathrm{N}$ during the lime addition process was assumed to be due to $\mathrm{NH}_{3}$ volatilisation (SI-4). It was assumed that biogas generated from the anaerobic digestion process was used to generate electricity and process heat to maintain the temperature of the reactor (SI-5). Biogas production was assumed to be $650 \mathrm{Nm}^{3}$ per tonne of volatile degraded solids $\left(59.5 \%\right.$ methane $\left(\mathrm{CH}_{4}\right)$ and $40.5 \%$ carbon dioxide $\left(\mathrm{CO}_{2}\right)$ ) and a leakage rate of $3 \%$ was assumed (Yoshida et al., 2014a, 2014b). Emissions associated with biogas combustion were taken from Nielsen et al. (2010).

The dewatering process was assumed to divert $42 \%$ of $\mathrm{N}$ and $28 \%$ of $\mathrm{P}$ contained in the sludge to the reject water. The reject water was sent back to the head of the WWTP, which is equipped to remove biological $\mathrm{N}$ and chemically precipitate $\mathrm{P}$ through the addition of iron salts (SI-6). The $\mathrm{P}$ removal efficiency in the WWTP was high, with more than $93 \%$ of $\mathrm{P}$ in wastewater ending in the sludge and $7 \%$ in the treated wastewater (effluent from the plant). In this study, a static approach was taken to model the treatment of reject water. In general, it was assumed that the pollutant removal efficiency of the wastewater treatment processes was the same for the treatment of the reject water and influent wastewater to the plant, and the treatment of the reject water was therefore not affected by the choice of sludge treatment technology. As $28 \%$ of $\mathrm{P}$ in the initial mixed sludge was diverted to the reject water stream and it was assumed that $7 \%$ of this was lost to the aquatic environment, $1.8 \%$ of $\mathrm{P}$ in the initial mixed sludge was lost during reject water treatment.

After land application, the fate of $\mathrm{C}, \mathrm{N}$ and $\mathrm{P}$ was modelled. For metals, the assumption was made that all metals in dewatered mixed sludge and digestate were introduced to agricultural soil. For $\mathrm{C}$ in sludge and digestate, depending on the sludge type, 5-7\% was sequestered in the soil, as shown by the simulation results of Bruun et al. (2016). A small fraction of $\mathrm{C}$ was assumed to be emitted as $\mathrm{CH}_{4}$ 
(0.05\% of input $\mathrm{C}$ for fresh digestate and $0.01 \%$ for the other sludge types (Ambus et al., 2001)). The remaining part of $\mathrm{C}$ applied to land was assumed to be converted to $\mathrm{CO}_{2}$ and emitted into the air.

In accordance with Bruun et al. (2016), it was assumed that $15 \%$ of the content of ammonical $\mathrm{N}\left(\mathrm{NH}_{4}{ }^{+}+\mathrm{NH}_{3}\right)$ in sludge and digestate was volatilised and lost as $\mathrm{NH}_{3}$ during spreading on land. As ammonical $\mathrm{N}$ constitutes a varying part of total $\mathrm{N}$ depending on the composition of sludge and digestate in the different scenarios, a varying share of total $\mathrm{N}$ was emitted as $\mathrm{NH}_{3}$. Some of the inorganic $\mathrm{N}$ applied to soil runs off to surface water or leaches through the soil profile below $3 \mathrm{~m}$, primarily as nitrate $\left(\mathrm{NO}_{3}{ }^{-}\right)$. In addition, $\mathrm{N}_{2} \mathrm{O}$ is produced in nitrification and denitrification processes and emitted to the atmosphere. Emission factors for the application of the four different sludge types were taken from Bruun et al. (2016), assuming application on a sandy loam soil with a medium precipitation regime for European conditions. These emission factors were based on a 100-year extrapolation of the results from a sludge soil-incubation study by Yoshida et al. (2015b) using the DAISY dynamic agricultural model. The rate of $\mathrm{CH}_{4}, \mathrm{NH}_{3}, \mathrm{NO}_{3}^{-}$and $\mathrm{N}_{2} \mathrm{O}$ emissions and $\mathrm{C}$ sequestration in the soil was quantified by multiplying the mass flow of each substance with the corresponding emission or sequestration factor. Bruun et al. (2016) suggest two sets of environmental emission factors depending on the fertilising status of the soil: high crop response conditions and low crop response conditions. High crop response conditions appear when $\mathrm{N}$ is the limiting factor for plant growth in the agricultural system and they lead to large plant yield response when $\mathrm{N}$ is added. In this study, environmental emission factors for high crop response conditions were used, as it was assumed that sewage sludge was applied on an arable farm with a low $\mathrm{N}$ status due to the regulatory system in Denmark. Any possible increment in plant yields caused by the application of sludge other than the saved application of mineral fertiliser was ignored in the current study. Emission and sequestration factors used in the LCA modelling for the scenarios with land application are presented in SI-7.

Phosphorus (P) applied with the sludge is primarily taken up by plants or bound to soil particles, but a small fraction ends up in water bodies, which was assumed to be $2.2 \%$ of $\mathrm{P}$ added to the field (Kronvang et al., 2005).

The environmental aspects of the avoided use of mineral fertiliser due to application of sewage sludge or digestate on land were modelled in two parts: $i$ ) avoided production of mineral fertiliser and ii) avoided emissions from the use of mineral fertiliser on land. In Denmark, the $\mathrm{N}$ fertiliser value of sewage sludge is considered to be $45 \%$ of $\mathrm{N}$ in mineral fertiliser under the regulation on nutrient 
management (Ministry of Environment and Food of Denmark, 2015). In other words, when calculating the amount of $\mathrm{N}$ fertiliser that can be applied to land according to the law, each $\mathrm{kg}-\mathrm{N}$ of sewage sludge replaces $0.45 \mathrm{~kg}-\mathrm{N}$ of mineral fertiliser. The Danish regulation does not provide a fertiliser replacement value for $\mathrm{P}$ in sewage sludge, but it does place a cap on how much $\mathrm{N}$ and $\mathrm{P}$ from sludge can be applied on land. Up to $170 \mathrm{~kg}-\mathrm{N}$ ha ${ }^{-1}$ per year or $90 \mathrm{~kg}-\mathrm{P} \mathrm{ha}{ }^{-1}$ over a period of three years can be applied from sludge. Sewage sludge is a P-rich organic fertiliser, so the amount of sludge that can be applied on land is limited by the maximum $\mathrm{P}$ application rate $\left(30 \mathrm{~kg} \mathrm{P} \mathrm{ha}^{-1} \mathrm{yr}^{-1}\right)$ rather than the maximum $\mathrm{N}$ application rate $\left(170 \mathrm{~kg}_{-} \mathrm{N} \mathrm{ha}{ }^{-1} \mathrm{yr}^{-1}\right)$. This can be seen from the $\mathrm{N}: \mathrm{P}$ ratio in the land-applied sludges, which varied between 1.08 and 1.54. As an example, if $30 \mathrm{~kg} \mathrm{P}^{-1}$ of sludge with an N:P ratio of 1.5 were applied, only $45 \mathrm{~kg} \mathrm{~N} \mathrm{ha}^{-1}$ would be applied along with the sludge. It was assumed that 1 ) the farmer applies the maximum organic fertiliser permitted under the $\mathrm{P}$ regulation, 2) the farmer does not add additional $\mathrm{P}$ in terms of mineral fertiliser, and 3) plant availability of sludge and digestate $\mathrm{P}$ is equal to mineral fertiliser P. The mineral $\mathrm{P}$ fertiliser substitution rate was determined by setting up a $\mathrm{P}$ balance for the crop rotation taking into consideration the recommended $\mathrm{P}$ fertiliser application rate for each crop and the application limit of $30 \mathrm{~kg}-\mathrm{P} \mathrm{ha}^{-1} \mathrm{yr}^{-1}$ from sludge (Ministry of Environment and Food of Denmark, 2006). The recommended $\mathrm{P}$ fertilisation was $21 \%$ lower than the actual $\mathrm{P}$ application with sludge, resulting in a $79 \%$ substitution of mineral $\mathrm{P}$ fertiliser. A detailed description of the calculations can be found in SI-7. There is no cap on the amount of potassium (K) application to soil and sludge has a low $\mathrm{K}$ content. Hence, a substitution rate of $100 \%$ was applied to mineral $\mathrm{K}$ fertiliser.

In the INC scenario, the incinerator was equipped with a sludge dryer. In order to make the sludge combustible, the solid content was increased to $35 \%$ by using heat from the sludge incineration oven. Sludge incineration generates flue gas and ash. The sludge incinerator is equipped with an electrostatic precipitator, wet scrubbers for flue gas treatment and a sludge dryer, which recovers heat from the incinerator. Bottom ash from sludge incineration is landfilled, with leachate collection and treatment. More information about incineration can be found in SI-8.

\subsection{Life cycle impact assessment}

Mid-point impacts for ten impact categories were assessed in this study. These were human toxicity carcinogenic effects, human toxicity non-carcinogenic effects, ecotoxicity, freshwater eutrophication, marine eutrophication, terrestrial eutrophication, terrestrial acidification, particulate 
matter formation, climate change and photochemical oxidant formation. The choice of an LCIA method for each impact category was made based on the recommendations made in the International Reference Life Cycle Data System (ILCD) handbook, which provides a list of LCIA methods considered to be the best at the time the evaluation commenced (Hauschild et al., 2013). The normalisation reference was taken from Laurent et al. (2013) and is presented in SI-9, along with LCIA methods and normalisation references. In this assessment, the depletion of abiotic resources was not included. $\mathrm{P}$ is the main abiotic resource that can be recovered from the spreading of sewage sludge on land. The supply risk associated with $\mathrm{P}$ stems from geopolitical instability rather than the depletion of ore, and the currently recommended scarcity-based characterisation method (CML, 2013) does not adequately address the issue of $\mathrm{P}$ recovery. Instead, the total amount of $\mathrm{P}$ recovered from land application is discussed along with the fate of $\mathrm{C}$ and $\mathrm{N}$ through the target systems.

\subsection{Uncertainty analysis}

The robustness of the results was analysed on two levels. First, a contribution analysis was performed to identify the unit processes influencing the overall outcome of the analyses. Second, the effects of local conditions (soil and precipitation patterns) on the overall outcome of the assessment were explored by applying emission factors for nine different soil and precipitation combinations (combinations of a coarse sandy soil, a sandy loam soil and a clay soil with a Danish precipitation regime of on average $605 \mathrm{~mm} \mathrm{yr}^{-1}$, a German regime of $563 \mathrm{~mm} \mathrm{yr}^{-1}$ and a Dutch regime of $828 \mathrm{~mm} \mathrm{yr}^{-}$ ${ }^{1}$ ). Emission factors for these combinations were based on the simulations carried out by Bruun et al. (2016).

\section{Results and discussion}

\subsection{Fate of $\mathrm{C}, \mathrm{N}$ and $\mathrm{P}$ in the modelled sludge treatment processes}

\subsubsection{Fate of carbon}

In relation to the fate of $\mathrm{C}$, it was evident that anaerobic digestion of mixed sludge prior to land application reduced the amount of $\mathrm{C}$ applied on agricultural land (Fig. 2a). In these scenarios, a significant proportion of the $\mathrm{C}$ in the mixed sludge was removed with the biogas. When sludge was 
only dewatered (DMS), more than $90 \%$ of the C contained in the mixed sludge was field applied, whereas the rate dropped to 33-36 \% when sludge was anaerobically treated (ADS and DADS). In the case of incineration (INC), more than $99 \%$ of $\mathrm{C}$ was lost as biogas or emitted into the atmosphere during incineration, mainly as $\mathrm{CO}_{2}$ and with small fractions of $\mathrm{CH}_{4}$ and carbon monoxide $(\mathrm{CO})$.

\subsubsection{Fate of nitrogen}

Sludge treatment only affected the fate of $\mathrm{N}$ in the LIMS scenario, in which lime stabilisation resulted in an $\mathrm{N}$ loss of $14 \%$ as volatilised $\mathrm{NH}_{3}$ induced by high $\mathrm{pH}$ conditions (Fig. 2b). Biogas combustion led to the emission of reactive and non-reactive $\mathrm{N}$. As the emissions of $\mathrm{N}_{2} \mathrm{O}$ and $\mathrm{NO}_{\mathrm{x}}$ were modelled as a fraction of biogas combusted, these were not directly linked to the $\mathrm{N}$ content in biogas, and were therefore not included in the expression of the fate of $\mathrm{N}$ in sludge. In total, $13 \%$ of $\mathrm{N}$ contained in the sludge was lost during biogas utilisation and assumed to be emitted as non-reactive $\mathrm{N}$. Incineration of anaerobically-digested sludge resulted in the additional emission of $50 \%$ of the input $\mathrm{N}$ in the mixed sludge as $\mathrm{N}_{2}$, resulting in a total of $63 \%$ of total $\mathrm{N}$ being emitted as non-reactive $\mathrm{N}$ during sludge treatment.

The reject water after dewatering of mixed sludge contained $42 \%$ of input $\mathrm{N}$, while the reject water after dewatering of anaerobically-digested sludge contained $36 \%$ of input $\mathrm{N}$. In both cases the reject water was injected back into the wastewater treatment process, where $58 \%$ of $\mathrm{N}$ contained in the reject water was removed as $\mathrm{N}_{2}$ through nitrification-denitrification and $9.3 \%$ was emitted to surface water. In the ADS scenario, no dewatering took place, leading to land application of $87 \%$ of $\mathrm{N}$ in the initial mixed sludge. Land application of $\mathrm{N}$ was lower in the other scenarios: $58 \%$ in DMS, $44 \%$ in LIMS and $50 \%$ in DADS.

Following land application, some of the $\mathrm{N}$ was lost to the surrounding environment in a reactive form $\left(\mathrm{NH}_{3}\right.$ volatilisation, $\mathrm{NH}_{4}{ }^{+}$and $\mathrm{N}_{2} \mathrm{O}$ emission, $\mathrm{NO}_{3}{ }^{-}$to surface water or $\mathrm{NO}_{3}^{-}$leaching to groundwater), some was lost in a non-reactive form with no environmental impact ( $\mathrm{N}_{2}$ emission), and some was incorporated into plant biomass or stayed in the organic matter in the soil. The ADS scenario resulted in the highest proportion of reactive $\mathrm{N}$ lost to the environment when applied on land (36\% of $\mathrm{N}$ in mixed sludge). Dewatering of anaerobically-digested sludge prior to land application resulted in a reduction of more than $50 \%$ in reactive- $\mathrm{N}$ losses (17\% of $\mathrm{N}$ in mixed sludge). Reactive $\mathrm{N}$ loss after land application for DMS was $19 \%$, while it was $29 \%$ for LIMS. Crop N uptake and soil N storage 
were highest for the ADS scenario with $23 \%$ and $15 \%$ of the initial $\mathrm{N}$ in mixed sludge respectively, followed by the DADS scenario (17\% crop uptake, $9 \%$ storage). The lowest crop $\mathrm{N}$ uptake and soil $\mathrm{N}$ storage showed for the LIMS scenario, at $4 \%$ and $7 \%$ respectively.

The removal of $\mathrm{N}$ is not considered a goal of sludge treatment, therefore scientific knowledge on the fate of $\mathrm{N}$ in the sludge treatment processes is limited. In a recent review on the effect of anaerobic digestion on the nutrient value of digestate, Möller and Müller (2012) found that the share of $\mathrm{NH}_{4}{ }^{+}$in total $\mathrm{N}$ increased by $10-33 \%$.

\subsubsection{Fate of phosphorus}

Phosphorus was emitted to the aquatic environment in two life cycle stages, namely in the reject water treatment and after land application (results not shown). In the ADS scenario, no dewatering took place and therefore all $\mathrm{P}$ contained in the sludge, $0.82 \mathrm{~kg}$, was applied to agricultural land, with a loss of $2.2 \%$. For the scenarios with dewatering, approximately $0.015 \mathrm{~kg} \mathrm{P}, 1.8 \%$ of total P input, was emitted to the aquatic environment during reject water treatment. In the DMS, LIMS and DADS scenarios, $0.74 \mathrm{~kg} \mathrm{P}$ was applied to agricultural land, while $2.0 \%$ of total $\mathrm{P}$ input was emitted after land application. In this study, P recovery from sludge incineration ash was not considered, although some technologies do exist to extract and recover P from sludge ash (Donatello and Cheeseman, 2013).

There is concern about the future supply of $\mathrm{P}$ since in current practice a considerable amount of $\mathrm{P}$ is wasted. As $\mathrm{P}$ is an essential and irreplaceable component for plants, animals and humans, use of $\mathrm{P}$ in a more sustainable way is necessary (European Commission, 2013). In the four scenarios with land application, $\mathrm{P}$ is recirculated, thus contributing to the sustainable use of $\mathrm{P}$.

\subsection{Life cycle assessment}

Figure 3 presents the contribution of the different life cycle stages of the sludge treatments to impacts that are normalised to person equivalents (PE) for ten impact categories for the five scenarios. More detailed results regarding contributing processes can be found in SI-10 in the Supplementary Information. Impact potentials are presented for five unit processes that are central to the treatment scenarios, namely sludge treatment, reject water treatment, transportation, land application and fertiliser substitution. Sludge treatment refers to treatments that took place after the mixed sludge was formed in the WWTP, such as dewatering, lime addition, anaerobic digestion and incineration. Reject 
water treatment included all the processes involved in wastewater treatment, as well as the downstream processes undergone by sludge formed from the treatment of reject water: sludge treatment, transportation, land application and fertiliser substitution.

\subsubsection{Toxicity}

Human toxicity non-carcinogenic and eco-toxicity showed the highest normalised impacts for all scenarios after land application. In both categories, impacts were dominated by the application of zinc $(\mathrm{Zn})$ to agricultural soil, accounting for $65-70 \%$ of the total ecotoxicity impact and $85-92 \%$ of the total human toxicity non-carcinogenic impact. For ecotoxicity, copper $(\mathrm{Cu})$ also contributed significantly to the impact (about 26-29\%). For human toxicity carcinogenic, the impact was two orders of magnitude smaller than for ecotoxicity and human toxicity non-carcinogenic. This is due to the fact that, in the present study, the amount of inorganic pollutants, which have carcinogenic effects on humans, was much smaller than the amount of metals, which have non-carcinogenic effects. The impact of human toxicity carcinogenic was dominated by mercury $(\mathrm{Hg})$ and lead $(\mathrm{Pb})$. Niero et al. (2014) assessed 460 WWTPs in Denmark and also reported high levels of human toxicity noncarcinogenic and ecotoxicity following the application of $\mathrm{Zn}$ and $\mathrm{Cu}$ to agricultural land.

Nonetheless, it should be noted that there are inherent problems in LCA toxicity impact assessments of $\mathrm{Zn}$ and $\mathrm{Cu}$. As reported by Gandhi et al. (2011), the toxicity characterisation factor in USETox for Zn could vary by a factor of 3 to 8, depending on local conditions such as $\mathrm{pH}$ in soil. Furthermore, $\mathrm{Cu}$ and $\mathrm{Zn}$ are essential nutrients (Goyer, 2004). While low concentrations are positive for plant growth and the nutritional value of the harvested crop, higher concentrations could potentially have negative effects on human and ecosystem health (Van Assche et al., 1996). For this reason, the mass loading approach adopted by toxicity evaluations in LCAs might not be appropriate for capturing the toxicity impacts of these metals. In fact, the soils that will probably receive sewage sludge are more likely to have low concentrations of $\mathrm{Zn}$ and $\mathrm{Cu}$ because these soils are on arable farms without application of animal manure, which contains $\mathrm{Zn}$ and $\mathrm{Cu}$ (Brock et al., 2006; Richards et al., 2011). To address this issue in an LCA context, Pizzol et al. (2011) excluded the nutritionally essential metals listed by Goyer (2004) from the assessment. If the same approach were to be applied here, the normalised impact for human toxicity non-carcinogenic would decrease by approximately $92 \%$ and 
ecotoxicity by approximately $99 \%$ and, in this case, $\mathrm{Hg}$ and $\mathrm{Pb}$ would become the dominant metals of concern.

The toxicity impacts for INC were 89-91\% smaller for human toxicity carcinogenic and $99.9 \%$ smaller for human toxicity non-carcinogenic and ecotoxicity compared to the other scenarios. This is because there was no land application, the incinerator was equipped with state-of-the-art flue gas treatment processes and the ash was landfilled with state-of-the-art leachate collection and treatment systems.

\subsubsection{Eutrophication}

For the eutrophication potentials, varying scenarios seemed beneficial depending on the receiving compartment in focus: ADS showed the lowest freshwater eutrophication as no reject water treatment occurred in this scenario, INC showed the lowest marine eutrophication because nothing was land applied, and DMS, DADS and INC showed the lowest terrestrial eutrophication due to the absence of sludge stabilisation and the associated emissions of $\mathrm{NH}_{3}$ and absence of or low $\mathrm{NH}_{3}$ after land application. The net freshwater eutrophication was mainly caused by emission of $\mathrm{P}$ from the reject water treatment. After land application there was also a substantial contribution to freshwater eutrophication, but this effect was counterbalanced by avoided emissions from mineral $\mathrm{P}$ fertiliser replacement. The net marine eutrophication was highest for the LIMS scenario, with contributions from $\mathrm{NH}_{3}$ from lime stabilisation and $\mathrm{NO}_{3}$ leaching and run-off after land application. The ADS scenario had the second highest marine eutrophication, due to large $\mathrm{NO}_{3}^{-}$leaching and run-off after land application. The net terrestrial eutrophication was highest for the LIMS scenario due to large $\mathrm{NH}_{3}$ emissions from lime addition, followed by the ADS scenario, which showed the largest contribution after land application. The terrestrial acidification for the five scenarios analysed showed the same trends as terrestrial eutrophication, only having comparable or lower normalised impacts.

\subsubsection{Particulate matter and climate change}

The particulate matter formation was almost negligible for the DMS scenario. It was highest for the LIMS scenario due to large emissions of particulate matter from lime stabilisation. Transportation and land application only contributed noticeably in the ADS scenario due to the 
relatively large diesel combustion in these processes. For the scenarios with anaerobic digestion, $\mathrm{SO}_{2}$ and $\mathrm{NH}_{3}$ emissions from biogas utilisation were the main contributors to particulate matter formation.

The trend for climate change appeared to be different from the other impact categories, as all five unit processes (sludge treatment, transportation, reject water treatment, land application and fertiliser substitution) associated with sludge management contributed to the overall impact within each scenario. In all scenarios (except for INC), land application contributed to climate change, mainly due to nitrous oxide $\left(\mathrm{N}_{2} \mathrm{O}\right)$ emissions during nitrification and denitrification processes in the fields. The $\mathrm{N}_{2} \mathrm{O}$ emissions were greatest for ADS. Furthermore, transportation of sludge contributed significantly to climate change in ADS due to the large volume of sludge being transported to the field in this scenario. Fertiliser substitution and anaerobic digestion of sludge contributed to savings in climate change. Savings related to fertiliser substitutions were mainly due to saved $\mathrm{N}_{2} \mathrm{O}$ emissions from the use of mineral fertiliser and avoided $\mathrm{CO}_{2}$ from the production of mineral fertiliser. As more $\mathrm{N}$ ended up in the fields in ADS compared to the other scenarios with land application, most mineral fertiliser was substituted in this scenario. Energy substitution through biogas utilisation contributed significantly to savings in climate change (ADS, DADS and INC). Climate change is an impact category often presented by previously published LCA studies on sewage sludge treatment, since reduction of the carbon footprint has been a focal point in many studies assessing sludge treatment alternatives (Yoshida et al., 2013). A range of impacts for climate change has been reported in previous studies: from 0.0015 to $0.002 \mathrm{PE}$ for lime stabilisation and from -0.0015 to $0.0037 \mathrm{PE}$ for dewatered sludge (Bridle and Skrypski-Mantle, 2000; Poulsen and Hansen, 2003; Murray et al., 2008; Peters and Rowley, 2009; Hong et al., 2009; Brown et al., 2010; Hospido et al., 2010). The present study's LIMS and DMS scenarios (0.0012 PE and 0.0035 PE) fell within the range reported by previous studies. Johansson et al. (2008) found that $\mathrm{N}_{2} \mathrm{O}$ emissions were the sole determining factor for climate change associated with nutrient recycling via sewage sludge utilisation in their analysis, whereas many other processes contributed to this in the present study's model.

\subsubsection{Other impact categories}

The photochemical oxidant formation showed the lowest normalised impacts of all impact categories analysed. A noticeable impact was shown only for ADS, mainly due to $\mathrm{NO}_{\mathrm{x}}$ and NMVOC 
403

404

405

406

407

408

409

410

411

412

413

414

415

416

417

418

419

420

421

422

423

424

425

426

427

428

429

430

431

432

(non-methane volatile organic compounds) emissions from diesel use during transportation and land application.

While the fate of $\mathrm{P}$ dominated only freshwater eutrophication, the fate of $\mathrm{N}$ had a profound effect on all the non-toxic impact categories other than freshwater eutrophication. Terrestrial eutrophication and marine eutrophication both depend solely (100\%) on the emission of reactive $\mathrm{N}$ to the environment, while $25-100 \%$ of terrestrial acidification, $12-97 \%$ of climate change, $19-100 \%$ of particulate matter formation and 54-80\% of photochemical oxidant formation were associated with reactive $\mathrm{N}$ emissions. For avoided impacts, the contribution of reactive $\mathrm{N}$ emissions was also $100 \%$ for marine eutrophication and terrestrial eutrophication, while it was smaller for the other impact categories. For terrestrial acidification it ranged from 34 to $49 \%$, for climate change from 1 to $55 \%$, for particulate matter formation from 1 to $4 \%$, and for photochemical oxidant formation from 70 to $86 \%$ (SI-11). Anaerobic digestion and sludge incineration decreased the emission of reactive $\mathrm{N}$ to the atmosphere.

In general, the INC scenario showed comparable (freshwater eutrophication, terrestrial eutrophication, particular matter formation, terrestrial acidification, climate change and photochemical oxidant formation) or lower (human toxicity non-carcinogenic, human toxicity carcinogenic, ecotoxicity and marine eutrophication) impacts than the scenarios including land application of sludge. Land application was the main contributor for the toxicity potentials and for freshwater eutrophication and marine eutrophication. However, these impact potentials were partly counterbalanced by the substitution of mineral fertiliser. In the ADS scenario, no reject water was generated and thus impacts from the dewatering and treatment of reject water were avoided. The LIMS scenario showed the highest impact potentials for marine eutrophication, terrestrial eutrophication, particular matter formation and terrestrial acidification due to emissions from lime stabilisation.

\subsection{Sensitivity to local conditions}

Figure 4 presents the results of the analysis in which emission factors for different local conditions across Europe (variations in precipitation and soil type) were evaluated in terms of impact potentials in marine eutrophication and climate change for the four scenarios including land application of sludge (scenarios DMS, LIMS, ADS and DADS). In some scenarios, variations in emission factors due to soil-precipitation combinations led to large differences in both marine eutrophication and 
climate change. The ADS scenario showed the greatest variation for marine eutrophication and climate change, depending on soil-precipitation combinations, with a factor 1.7 difference between the highest and lowest values. For marine eutrophication, the ADS scenario clearly showed the influence of the precipitation regime on marine eutrophication, with low precipitation (Germany) leading to the smallest impact potential and high precipitation (The Netherlands) leading to the greatest impact potential.

The ranking of scenarios depended on the soil-precipitation combinations for marine eutrophication, with the DADS scenario performing best for all soil types and precipitation regimes, unless there was a low precipitation regime (Germany). With low precipitation on a coarse sandy soil and a sandy loam soil DMS performed best, while ADS scenario performed best on a clay soil in Germany. The LIMS scenario performed worst in almost all cases, apart from a medium or high precipitation regime on a coarse sandy soil. In these specific cases, the ADS scenario performed worst. The ranking of scenarios was not affected by soil-precipitation combinations for climate change. The DADS scenario always performed best, the ADS scenario always performed worst, and the DMS and LIMS scenarios performed equally and intermediately between ADS and DADS. After land application, mainly emissions of $\mathrm{N}_{2} \mathrm{O}$ contributed to climate change. As these values were fairly equal for the different soil and precipitation types, the climate change was not affected that much. The results indicate that local weather and soil conditions affected the results significantly. It is important to be consistent with the choice of inventory data since emission factors depend on sludge type (treatment prior to land application) and regional conditions (soil, climate etc.).

\section{Conclusions}

The current LCA pointed at human toxicity non-carcinogenic and ecotoxicity as being the impact categories of highest concern for sewage treatment technologies. The impact potentials were mainly caused by $\mathrm{Zn}$ and $\mathrm{Cu}$ application with the sludge. However, the impact assessment method inadequately accounted for the $\mathrm{Zn}$ and $\mathrm{Cu}$ content in the soil. These elements are essential plant nutrients and in small concentrations are necessary for optimal crop growth. In soils where no or only mineral fertiliser is applied, $\mathrm{Zn}$ and $\mathrm{Cu}$ could actually be in deficit in the soil. It was found that the sludge treatment technology shifted the timing of $\mathrm{C}$ and $\mathrm{N}$ emissions. For terrestrial eutrophication, terrestrial acidification and particular matter formation, emissions from sludge treatment (lime 
stabilisation and anaerobic digestion) were the dominant contributors, while for the remaining categories (human toxicity non-carcinogenic, ecotoxicity, freshwater eutrophication, marine eutrophication, human toxicity carcinogenic and climate change), land application was the life cycle stage with the greatest impact potential, while fertiliser substitution accounted for the greatest impact savings. The INC scenario performed comparably to or better than the other scenarios including land application of sludge. This scenario in particular performed better for the human toxicity noncarcinogenic, human toxicity carcinogenic, ecotoxicity and marine eutrophication impact categories. Dewatering of anaerobically-digested sludge reduced emissions of reactive $\mathrm{N}$ after land application, while the treatment of reject water resulted in the removal of $\mathrm{N}$ as $\mathrm{N}_{2}$ via nitrification-denitrification processes. Reject water treatment mainly contributed to freshwater eutrophication due to P loss in the effluent. Finally, it was evident that omitting land application or reject water treatment from LCA studies on sludge treatment, a frequently seen phenomenon, results in the improper depiction of the environmental performance of sludge management alternatives. Regional factors such as soil type and precipitation regime have a profound influence on marine eutrophication and climate change, with different ranking of scenarios for marine eutrophication, depending on the chosen conditions. Overall, the present study highlights the importance of including all sludge treatment stages and conducting a detailed $\mathrm{N}$ flow analysis, since the emission of reactive $\mathrm{N}$ into the environment is the major driver for almost all non-toxic impact categories.

\section{Acknowledgements}

The work was funded by the Residual Resource Research (3R) graduate school at the Technical University of Denmark.

\section{References}

Ambus, P., Jensen, J.M., Prieme, A., Pilegaard, K., Kjøller, A., 2001. Assessment of $\mathrm{CH}_{4}$ and $\mathrm{N}_{2} \mathrm{O}$ fluxes in a Danish beech (Fagus sylvatica) forest and an adjacent $\mathrm{N}$ fertilized barley (Hordeum vulgare) field: effects of sewage sludge amendments. Nutr. Cycl. Agroecosyst., 60, 15-21. 
Basso, B., Ritchie, J.T., 2005. Impact of compost, manure and inorganic fertilizer on nitrate leaching and yield for a 6-year maize-alfalfa rotation in Michigan. Agric. Ecosyst. Environ., 108, 329-341.

Bridle, T., Skrypski-Mantele, S., 2000. Assessment of sludge reuse options: A life-cycle approach. Water Sci. Technol., 41, 131-135.

Brock, E. H., Ketterings, Q. M., McBride, M.2006. Copper and zinc accumulation in poultry and dairy manure amended fields. Soil Sci., 171 (5), 388-399.

Brown, S., Beecher, N., Carpenter, A., 2010. Calculator tool for determining greenhouse gas emissions for biosolid processing and end use. Environ. Sci. Technol., 44, 9509-9515.

Bruun, S., Yoshida, H., Nielsen, M., Jensen, L.S., Christensen T.H., Scheutz, C., 2016. Estimation of long-term environmental inventory factors associated with land application of sewage sludge. J. Clean Prod., 126, 440-450.

Cabrera, M.L., Kissel, D.E., Vigil, M.F., 2005. Nitrogen mineralization from organic residues: Research opportunities. J. Environ. Qual., 34, 75-79.

Clavreul, J., Baumeister, H., Christensen T.H., Damgaard A., 2014. An environmental assessment system for environmental technologies. Environ. Modell. Softw., 60, 18-30.

CML, 2013. CML-IA database containing characterisation and normalisation factors (version 4.2; updated in April 2013). Available at: http://cml.leiden.edu/software/data-cmlia.html. Accessed 05/2013.

Donatello, S., Cheeseman, C.R., 2013. Recycling and recovery routes for incinerated sewage sludge ash (ISSA): A review. Waste Manage., 33, 2328-2340. 
European Commission, 2013. Consultative Communication on the Sustainable Use of Phosphorus. European Commission, Directorate General for the Environment, Brussels, Belgium. Retrieved from http://ec.europa.eu/environment/consultations/phosphorus_en.htm.

Fytili, D., Zabaniotou, A., 2008. Utilization of sewage sludge in EU application of old and new methods - A review. Renew. Sust. Energ. Rev., 12, 116-140.

Gandhi, N., Diamond, M.L., Huijbregts, M.A.J., Guinee, J.B., Peijnenburg, W.J.G.M., van de Meent, D., 2011. Implication of considering metal bioavailability in estimate of freshwater ecotoxicity of two case studies. Int. J. Life Cycle Assess., 16, 774-787.

Goyer, R., 2004. Issue Paper on the human heath effect of metals. US Environmental Protection Agency. Risk assessment forum 2004. Retrieved from http://www.epa.gov/raf/publications/pdfs/HUMANHEALTHEFFECTS81904.PDF.

Johansson, K., Perzon, M., Froling, M., Mossakowska, A., Svanstrom, M., 2008. Sewage sludge handling with phosphorus utilization - life cycle assessment of four alternatives. J. Clean Prod., 16, 135-151.

Kronvang, B., Bechmann, M., Lundekvam, H., Behrendt, H., Rubæl, G.H., Schoumans, O.F., Syversen N., Andersen H.R., Hoffmann, C.C., 2005. Phosphorus losses from agricultural areas in river basins: Effects and uncertainties of targeted mitigation measures. J. Environ. Qual., 34, 2129-2144.

Hauschild, M.Z., Goedkoop, M., Guinee, J., Heijungs, R., Huijbregts, M., Jolliet, O., Margini, M., Schryver, A.D., Humbert, S., Laurent, A., Sala, S., Pant, R., 2013. Identifying best existing practice for chracterization modeling in life cycle impact assessment. Int. J. Life Cycle Assess., 18, 683-697.

Hong, J., Hong, J., Otaki, M., Jolliet, O., 2009. Environmental and economic life cycle assessment for sewage sludge treatment processes in Japan. Waste Manage., 29, 696-703 
Hospido, A., Carballa, M., Moreira, M., Omil, F., Lema, J.M., Feijoo, G., 2010. Environmental assessment of anaerobically digested sludge reuse in agriculture: Potential impacts of emerging micropollutants. Water Res. , 44, 3225-3233

IPCC, 2006. IPCC Guidelines for national greenhouse gas inventories, prepared by the National Greenhouse Gas Inventories Programme, Eggleston H.S., Buendia L., Miwa K., Ngara T. and Tanabe K. (Eds). IGES, Japan.

Lal, R., 2004. Soil carbon sequestration to mitigate climate change. Geoderma, 123, 1-22.

Laurent, A., Hauschild, M.Z., Golsteijn, L., Simas, M., Fontes, J., Wood, R., 2013. Prosuite Deliverable 5.2: Normalization factors for environmental, economic and socio-economic indicators. Retrieved from http://46.105.145.85/c/document_library/get_file?uuid=750ef6d0-4e9d-4a00-913c3f4cfd632782\&groupId=12772.

Ministry of Environment and Food of Denmark, 2015. Vejledning om gødsknings- og harmoniregler. Planperioden 1. august 2015 til 31. juli 2016. Miljø- og Fødevareministeriet: Copenhagen, Denmark: pp 166.. ISBN 978-87-7120-771-2.

Ministry of Environment and Food of Denmark, 2006. Bekendtgørelse om anvendelse af affald til jordbrugsformål (Slambekendtgørelsen). BEK nr 1650 of December 13, 2006.

https://www.retsinformation.dk/forms/R0710.aspx?id=13056.

Morée, A.L., Beusen, A.H.W., Bouwman, A.F., Willems, W.J., 2013. Exploring global nitrogen and phosphorus flows in urban wastes during the twentieth century. Glob. Biogeochem. Cycle, 27, 836-846.

Murray, A., Horvath, A., Nelson, K.L., 2008. Hybrid life-cycle environmental and cost inventory of sewage sludge treatment and end-use scenarios: A case study from China. Environ. Sci. Technol., 42, 3163-3169 
Möller, K., Müller, T., 2012. Effect of anaerobic digestion on digestate nutrient availability and crop growth: A review. Eng. Life Sci., 12, 242-257.

Nielsen, M., Nielsen, O.-K. \& Thomsen, M. 2010: Emissions from decentralised CHP plants 2007 Energinet.dk Environmental project no. 07/1882. Project report 5 - Emission factors and emission inventory for decentralised CHP production. National Environmental Research Institute, Aarhus University. 113 pp. - NERI Technical report No. 786. http://www.dmu.dk/Pub/FR786.pdf.

Niero, M., Pizzol, M., Bruun, H.G., Thomsen, M., 2014. Comparative life cycle assessment of wastewater treatment in Denmark including sensitivity and uncertainty analysis. J. Clean Prod., 68, 2535 .

Peters, G.M., Rowley, H.V., 2009 Environmental comparison of biosolids management systems using life cycle assessment. Environ. Sci. Technol., 43, 2674-2679

Pizzol, M., Christensen, P., Schmidt, J., Thomsen, M., 2011. Impact of "metals" on human health: a comparison between nine different methodologies for Life Cycle Impact Assessment (LCIA). J. Clean Prod., 19, 646-656.

Poulsen, T.G., Hansen, J.A., 2003. Strategic environmental assessment of alternative sewage sludge management scenarios. Waste Manage. Res., 21, 19-28.

Qiao, M., Zheng, Y.M., Zhu, Y.G., 2011. Material flow analysis of phosphorus through food consumption in two megacities in northern China. Chemosphere 84, 773-778.

Richards, J.R., Zhang, H., Schroder, J.L., Hattey, J.A., Raun, W.R., Payton, M.E,, 2011.Micronutrient availability as affected by the long-term application of phosphorus fertilizer and organic amendments. Soil Sci. Soc. Am. J., 75 (3), 927-939. 
609 Singh, R.P., Agrawal, M., 2008. Potential benefits and risks of land application of sewage sludge. 610 Waste Manage., 28, 347-358.

611

612 613 614

Schmid, M., Neftel, A., Fuhrer, J., 2000. Lachgasemissionen aus der Schweizer Landwirtschaft. FALSchriftenreihe 33. Forschungsanstalt für Agrarökologie und Landbau (FAL), Zürich-Reckenholz.

Schmid, M., Neftel, A., Riedo, M., Fuhrer, J., 2001. Process-based modelling of nitrous oxide from different nitrogen sources in mown grassland. Nutr. Cycl. Agroecosyst., 60, 177-187.

Van Assche, F., Van Tilborg, W., Waeterschoot, H., 1996. Environmental risk assessment for essential elements case study: zinc, in International Council on Metals and the Environment, Report of the International Workshop on Risk Assessment of Metals and their Inorganic Compounds. ICME, Ottawa, Canada, pp. 171-180. Retrieved from http://www.icmm.com/document/140.

Yoshida, H., Christensen, T.H., Scheutz, C., 2013. Life cycle assessment of sewage sludge management: a review. Waste Manage. Res., 31, 1083-1101.

Yoshida, H., Clavreul, J., Christensen T.H., Scheutz, C., 2014a. Influence of data collection schemes on the Life Cycle Assessment of a municipal wastewater treatment plant. Water Res., 56, 292-303.

Yoshida, H., Mønster, J., Scheutz, C., 2014b. Plant integrated measurement of methane and nitrous gas from wastewater treatment plant. Water Res., 61, 108-118.

Yoshida, H., Christensen, T.H., Guildal, T., Scheutz, C., 2015a. A comprehensive substance flow analysis of a municipal wastewater and sludge treatment plant. Chemosphere, 138, 874-882.

Yoshida, H., Nielsen, M.P., Scheutz, C., Jensen, L.S., Christensen, T.H., Nielsen, S., Bruun, S., 2015 b. Effects of sewage sludge stabilization on fertilizer value and greenhouse gas emissions after soil application. Acta Agric. Scand. Sect. B-Soil Plant Sci., 65, 506-516. 


\begin{tabular}{|c|c|c|c|c|c|c|}
\hline $\begin{array}{l}\text { Mixed } \\
\text { sludge }\end{array}$ & & \multirow[t]{2}{*}{$\begin{array}{l}\text { Mechanical } \\
\text { dewatering }\end{array}$} & \multirow{2}{*}{\multicolumn{2}{|c|}{ treatment }} & Land application & \multirow[t]{2}{*}{$\begin{array}{l}\text { Fertiliser production } \\
\text { and use }\end{array}$} \\
\hline DMS & & & & & & \\
\hline $\begin{array}{l}\text { Mixed } \\
\text { sludge }\end{array}$ & & $\begin{array}{l}\text { Mechanical } \\
\text { dewatering }\end{array}$ & $\rightarrow \begin{array}{c}\text { Lime } \\
\text { addition }\end{array}$ & $\mathrm{T}$ & Land application & $\begin{array}{l}\text { Fertiliser production } \\
\text { and use }\end{array}$ \\
\hline LIMS & & & $\begin{array}{l}\text { Reject water } \\
\text { treatment }\end{array}$ & & & \\
\hline $\begin{array}{l}\text { Mixed } \\
\text { sludge }\end{array}$ & $\begin{array}{l}\text { Anaerobic } \\
\text { digestion }\end{array}$ & & & $\mathrm{T}$ & Land application & $\begin{array}{l}\text { Fertiliser production } \\
\text { and use }\end{array}$ \\
\hline ADS & $\rightarrow \quad \begin{array}{c}\text { Biogas } \\
\text { utilisation }\end{array}$ & «-- Electricity & & & & \\
\hline $\begin{array}{l}\text { Mixed } \\
\text { sludge }\end{array}$ & $\begin{array}{l}\text { Anaerobic } \\
\text { digestion }\end{array}$ & $\begin{array}{l}\text { Mechanical } \\
\text { dewatering }\end{array}$ & & $\mathrm{T}$ & Land application & $\begin{array}{l}\text { Fertiliser production } \\
\text { and use }\end{array}$ \\
\hline DADS & $\Rightarrow \begin{array}{c}\text { Biogas } \\
\text { utilisation }\end{array}$ & Electricity & $\begin{array}{l}\text { Reject water } \\
\text { treatment }\end{array}$ & & & \\
\hline $\begin{array}{l}\text { Mixed } \\
\text { sludge }\end{array}$ & $\begin{array}{l}\text { Anaerobic } \\
\text { digestion }\end{array}$ & $\rightarrow \begin{array}{l}\text { Mechanical } \\
\text { dewatering }\end{array}$ & $\longrightarrow$ Incineration & $\mathrm{T}$ & $\rightarrow$ Ash landfill & \\
\hline INC & $\begin{array}{c}\text { Biogas } \\
\text { utilisation }\end{array}$ & «-- Electricity & $\begin{array}{c}\text { Reject water } \\
\text { treatment }\end{array}$ & & & \\
\hline
\end{tabular}

Figure 1. Unit processes included in the five sludge management options: DMS (mechanically

641 dewatered mixed sludge followed by land application), LIMS (lime addition to mechanically dewatered 642 sludge followed by land application), ADS (anaerobic digestion followed directly by land application), 643 DADS (dewatered anaerobically-digested sludge followed by land application) and INC (incineration 644 of dewatered anaerobically-digested sludge and landfilling of ash), $\mathrm{T}$ is transportation 

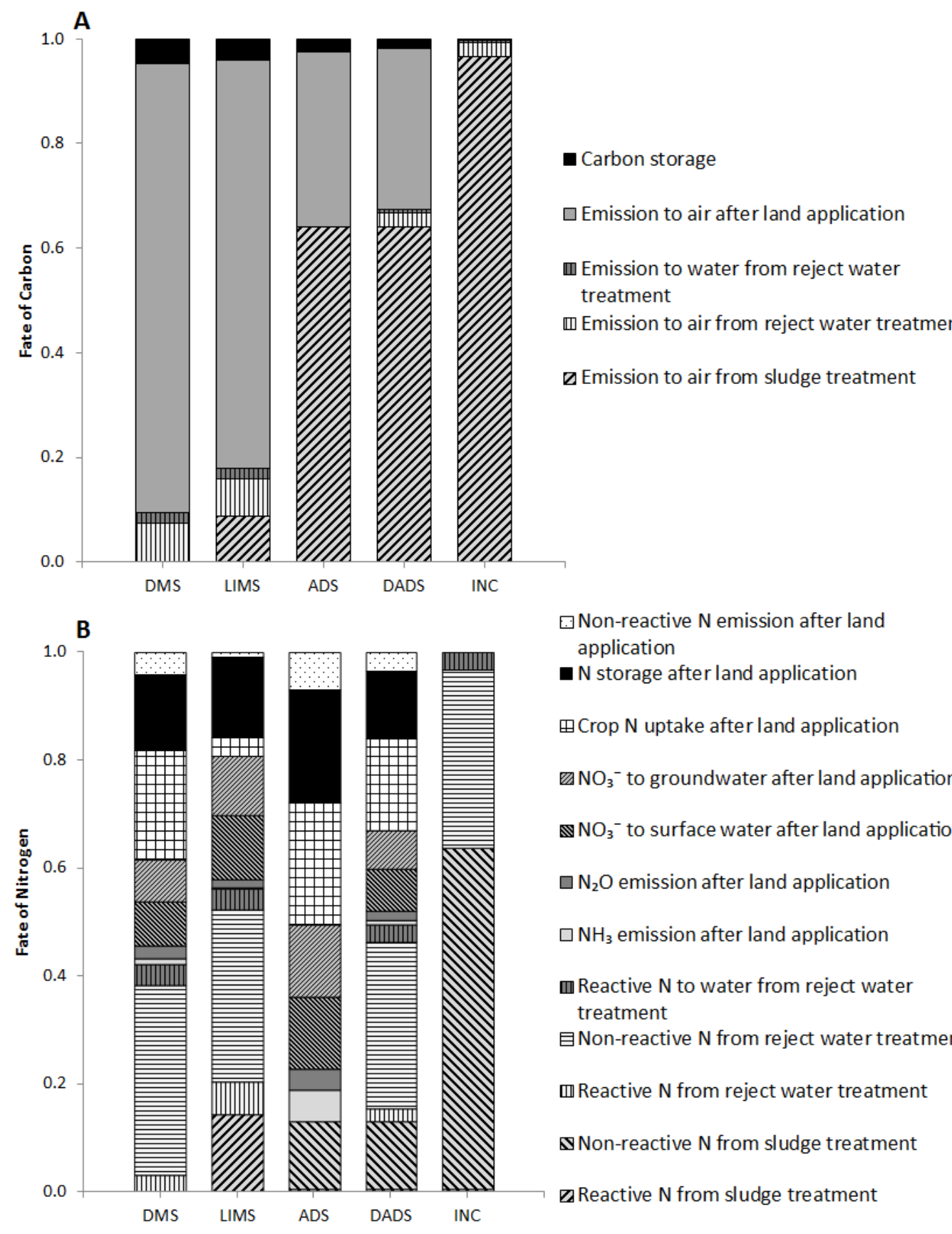

648 Figure 2. Fate of carbon (A) and nitrogen (B) in mixed sewage sludge in the five management options: 649 DMS (mechanically dewatered mixed sludge followed by land application), LIMS (lime addition to 650 mechanically dewatered sludge followed by land application), ADS (anaerobic digestion followed 651 directly by land application), DADS (dewatered anaerobically-digested sludge followed by land 652 application) and INC (incineration of dewatered anaerobically-digested sludge and landfilling of ash) 

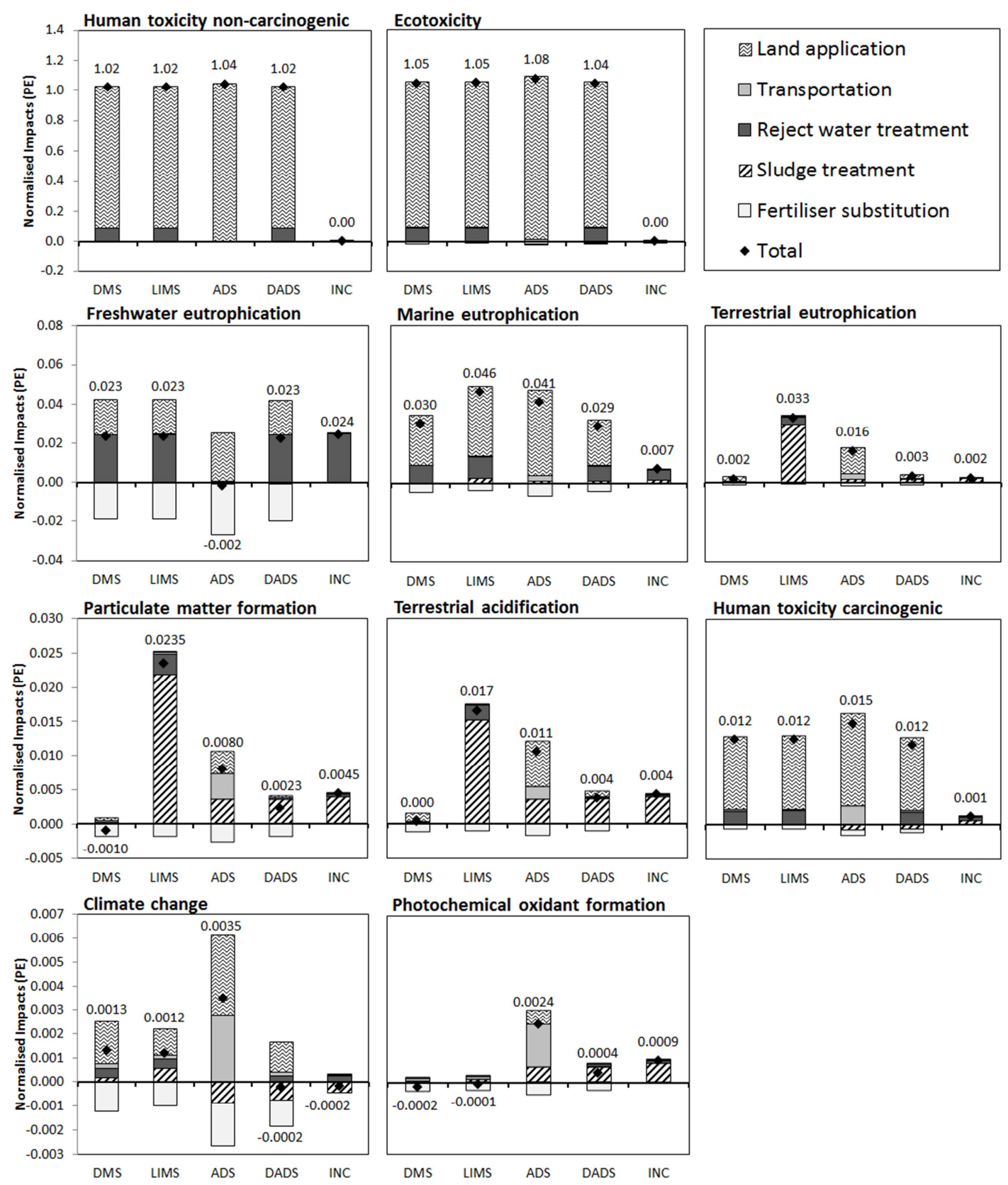

654 Figure 3. Normalised impacts (in person equivalents, PE) of the five treatments reported for the five unit processes contributing to the sludge management options. The five sludge management options are DMS (mechanically dewatered mixed sludge followed by land application), LIMS (lime addition to 657 mechanically dewatered sludge followed by land application), ADS (anaerobic digestion followed 658 directly by land application), DADS (dewatered anaerobically-digested sludge followed by land application) and INC (incineration of dewatered anaerobically-digested sludge and landfilling of ash) 
Marine eutrophication

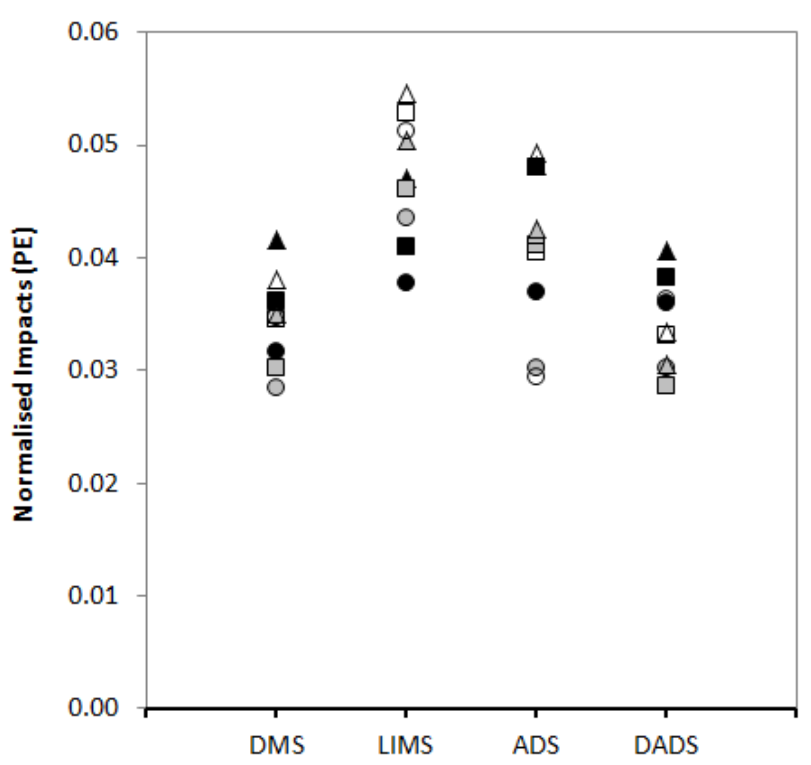

Climate change

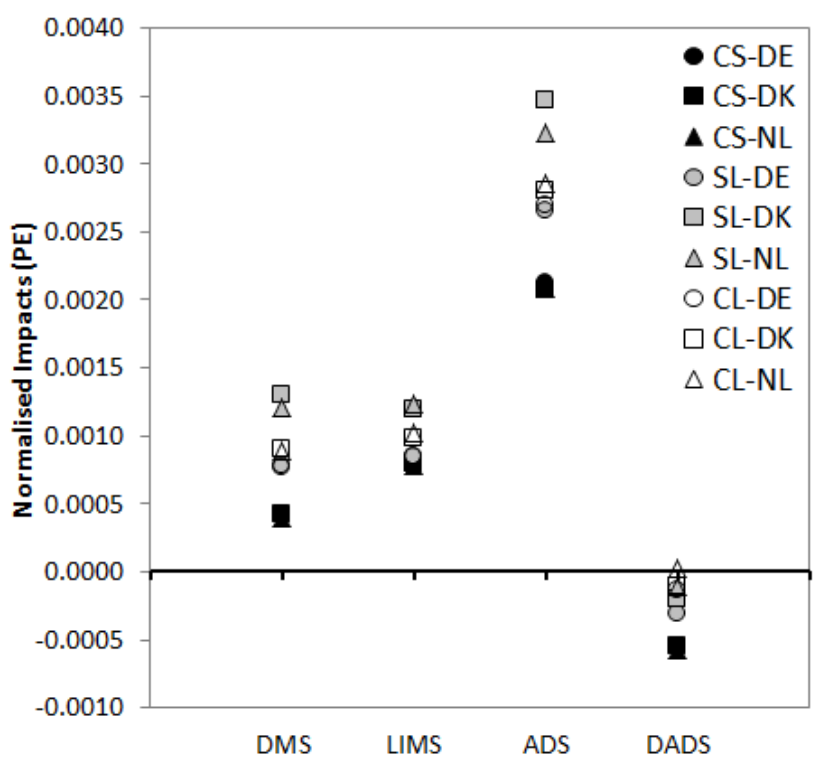

Figure 4. Variation in marine eutrophication and climate change caused by soil and precipitation

662 combinations. The four sludge management options are DMS (mechanically dewatered mixed sludge 663 followed by land application), LIMS (lime addition to mechanically dewatered sludge followed by land 664 application), ADS (anaerobic digestion followed directly by land application), DADS (dewatered 665 anaerobically-digested sludge followed by land application) and INC (incineration of dewatered 666 anaerobically-digested sludge and landfilling of ash)

667 Abbreviations:

668 CS: coarse sandy soil

669 - SL: sandy loam soil

670 - CL: clay soil

671 - DK: Denmark, medium precipitation of $605 \mathrm{~mm} \mathrm{yr}^{-1}$

672 - DE: Germany, low precipitation of $563 \mathrm{~mm} \mathrm{yr}^{-1}$

673 - NL: The Netherlands, high precipitation of $828 \mathrm{~mm} \mathrm{yr}^{-1}$ 


\section{Highlights}

- Five sludge treatment scenarios were compared using life cycle assessment

- Sludge incineration led to lower or comparable impact potentials as land application

- Toxicity showed highest normalized impacts due to land application of $\mathrm{Zn}$ and $\mathrm{Cu}$

- Sludge treatment technology influenced in which processes $\mathrm{C}$ and $\mathrm{N}$ emissions occurred

- Inclusion of all treatment stages and performance of $\mathrm{N}$ flow analysis are important 